Article

\title{
Immobilized 2,2,6,6-tetramethyl-piperidinyl-1-oxy catalyst on polymer microspheres and its catalytic oxidation of benzyl alcohol with molecular oxygen
}

\author{
Yiling Yu, Baojiao Gao*, Yanfei Li \\ Department of Chemical Engineering, North University of China, Taiyuan 030051, Shanxi, China
}

\section{A R T I C L E I N F O}

Article history:

Received 12 May 2013

Accepted 2 July 2013

Published 20 September 2013

Keywords:

Poly(glycidyl methacrylate)

Nitroxide free radical

Immobilization

Alcohol oxidation

Molecular oxygen

\begin{abstract}
A B S T R A C T
Crosslinked polymer (glycidyl methacrylate) microspheres (CPGMA) were prepared with glycidyl methacrylate as monomer and ethylene dimethacrylate as crosslinker by suspension polymerization. The ring opening reaction between the epoxy groups on the CPGMA microspheres and 4-hydroxy-2,2,6,6-tetramethyl-piperidinyl-1-oxy (4-OH-TEMPO) was carried out to immobilize TEMPO on the polymer microspheres. TEMPO-immobilized microspheres (TEMPO/CPGMA) were obtained and were characterized by several methods. The effects of the main factors in the immobilization were examined so that the reaction conditions were optimized. On this basis, a co-catalyst system was constituted with TEMPO/CPGMA and $\mathrm{CuCl}$ and was used in the oxidation reaction of benzyl alcohol by molecular oxygen. The catalytic activity of the co-catalyst system and the effects of the main factors were examined. The experimental results showed that the ring opening reaction of the epoxy group allowed the immobilization of TEMPO to be smoothly realized on the CPGMA polymer microspheres, on which there were many epoxy groups. The ring opening reaction of the epoxy group is a nucleophilic substitution reaction with the $\mathrm{S}_{\mathrm{N}} 2$ reaction mechanism, and $N, N^{\prime}$-dimethyl formamide with a strong polarity is an appropriate solvent and a suitable temperature is $85^{\circ} \mathrm{C}$. The co-catalyst system consisting of the heterogeneous catalyst TEMPO/CPGMA and $\mathrm{CuCl}$ efficiently catalyzed the oxidation reaction of benzyl alcohol by molecular oxygen. Under mild conditions, benzyl alcohol was transformed to benzaldehyde with $100 \%$ selectivity and a yield of $90 \%$. The suitable molar ratio of the main catalyst TEMPO/CPGMA to the co-catalyst $\mathrm{CuCl}$ is 1:1.2 and the suitable amount of TEMPO/CPGMA is $0.90 \mathrm{~g}$. The TEMPO/CPGMA catalyst has excellent recyclability.
\end{abstract}

(C) 2013, Dalian Institute of Chemical Physics, Chinese Academy of Sciences. Published by Elsevier B.V. All rights reserved.

\section{Introduction}

The oxidation of alcohols to carbonyl compounds is one of the most important chemical transformations in organic synthesis. Traditionally, the oxidation is accomplished by stoichiometric and strong oxidants $\left(\mathrm{CrO}_{3}, \mathrm{KMnO}_{4}, \mathrm{MnO}_{2}\right.$, etc.), which have a number of disadvantages, such as harsh reaction conditions, large amounts of waste that pollute the environment, and high cost of oxidants [1-4]. Green environmental protection and high atom economy are required in today's chemical processes, but the traditional transformations cannot meet these requirements. Therefore, it is necessary to develop a highly efficient and environment friendly oxidation process of alcohols to carbonyl compounds, in which a catalyst with high performance is very important. Besides heteropolyacids and metalloporphyrins [5,6], nitroxide free radicals are highly efficient

\footnotetext{
*Corresponding author. Tel: +86-351-3924795; Fax: +86-351-3922118; E-mail: gaobaojiao@126.com This work was supported by the Natural Science Foundation of Shanxi Province (201002100843). 
catalysts for the oxidation of alcohol. Among the nitroxide free radicals, 2,2,6,6-tetramethyl-piperidinyl-1-oxy (TEMPO) has attracted much attention as a homogeneous catalyst. First, TEMPO is readily converted into a nitrogen carbonyl cation by a single electron oxidation, after which the nitrogen carbonyl cation, as a strong oxidant, enables primary and secondary alcohols to be quickly oxidized into the corresponding aldehyde or ketone with high conversion rate and high selectivity [7-10]. Also, by using TEMPO as the catalyst, the oxidation of alcohols can be carried out under mild conditions and with environment friendly oxidants, such as hydrogen peroxide and molecular oxygen [11-17]. Therefore, the use of TEMPO as the catalyst can achieve green synthesis. Moreover, the TEMPO catalyst has high stability because of the strong steric hindrance around the nitrogen groups [15].

Although TEMPO as a homogeneous catalyst exhibits good catalytic activity and selectivity, it is difficult to separate and recover TEMPO after the reaction, which severely restricts the development of the catalyst system. Immobilized TEMPO catalysts (heterogeneous TEMPO catalyst) on solid supports can overcome this shortcoming, and it also has some new catalytic characteristics, such as higher activity and is active without a co-catalyst $[10,18]$. The immobilization of TEMPO is one of the most important subjects in the study of catalytic oxidation. TEMPO has been immobilized on various solid supports, including silica gel, molecular sieves, and polymeric resins [19-21]. Among these supports, the polymer resin has received much attention as it is easy to introduce active groups on it by means of chemical modification, which facilitate the chemical bonding of TEMPO on these resins. For instance, researchers have prepared immobilized TEMPO catalyst by the bonding reaction between 4-hydroxy-2,2,6,6-tetramethyl-piperidinyl-1-oxy (4-OH-TEMPO) and the groups on the polymeric carriers, including carboxyl groups (or anhydride groups) and halide alkyl groups [22-24].

In our present investigation, crosslinked polymer (glycidyl methacrylate) (CPGMA) microspheres were first prepared by suspension polymerization. Then TEMPO was immobilized on the CPGMA microspheres by the ring opening reaction between 4-OH-TEMPO and epoxy groups on the CPGMA microspheres, and a novel TEMPO/CPGMA heterogeneous catalyst was thus obtained. TEMPO/CPGMA was used as the heterogenous catalyst for the oxidation of benzyl alcohol with molecular oxygen as an oxygen source. TEMPO/CPGMA exhibited high catalytic activity and excellent selectivity, and effectively transformed benzyl alcohol into benzaldehyde at room temperature. The mechanism of the heterogeneous catalytic oxidation reaction was explored.

\section{Experimental}

\subsection{Preparation of crosslinked microspheres CPGMA}

The crosslinked microspheres were prepared by suspension copolymerization of glycidyl methacrylate (GMA, AR grade, purchased from Nanhang Chemical Ltd, Suzhou, China, and purified by distillation under vacuum) and ethylene dimethac- rylate (EGDMA, Industrial grade, obtained from Kaihua Chemical Limited Company, Yantai, China, and purified by distillation under vacuum) with azoisobutyronitrile (AR grade, purchased from Shanghai Chemical Reagent Plant, Shanghai, China, and recrystallized by standard procedures) as initiator. The continuous phase consisted of $50 \mathrm{~mL}$ distilled water containing $0.50 \mathrm{~g}$ polyvinyl alcohol (reagent grade, purchased from Sanwei Chemical Plant, degree of polymerization $=1799$, Shanxi, China) and $3.50 \mathrm{~g} \mathrm{NaCl}$, which were used as dispersant and suspension stabilizer. The continuous phase was placed in a four-necked flask equipped with a mechanical stirrer, $\mathrm{N}_{2}$ inlet, and a condenser. GMA (10.0 mL) was mixed with $1.0 \mathrm{~mL}$ EGDMA as the oil phase, which was used as the dispersed phase. The dispersed phase was added dropwise into the continuous phase slowly. The agitating speed was adjusted and the reaction mixture was stirred for $30 \mathrm{~min}$ at $45^{\circ} \mathrm{C}$ to ensure good mixing of the two phases. The reactor was placed in a thermostat water bath, and when the mixture temperature was $55^{\circ} \mathrm{C}$, the initiator $(0.10 \mathrm{~g})$ was added, and under a nitrogen atmosphere, the copolymerization was carried out at $55^{\circ} \mathrm{C}$ for $5 \mathrm{~h}$. After the reaction, the microspheres were filtered off and washed with distilled water and ethanol in turn. Finally, the product was dried under vacuum at $50{ }^{\circ} \mathrm{C}$, and white translucent crosslinked GMA/EGDMA microspheres were obtained. Because GMA was the main monomer, they were named CPGMA.

\subsection{Preparation of immobilized microspheres TEMPO/CPGMA}

CPGMA microspheres were placed in a four-necked flask equipped with a mechanical stirrer, $\mathrm{N}_{2}$ inlet, and a condenser, followed by adding $N, N^{\prime}$-dimethyl formamide (DMF, AR grade, purchased from Tientsin Dibo Chemical Reagent Plant, Tianjin, China) as solvent. The microspheres were soaked and swelled for $12 \mathrm{~h}$. 4-OH-TEMPO (2.14 g, chemically pure, supplied from Ruishuo Chemical Limited Company, Shanghai, China) were dissolved in $30 \mathrm{~mL}$ of DMF, and the mixture was added into the four-necked flask. After that, a saturated $\mathrm{Na}_{2} \mathrm{CO}_{3}$ solution ( 5 $\mathrm{mL}$ ) as catalyst was added into the reaction system. The quaternization reaction was carried out for $12 \mathrm{~h}$ at $85{ }^{\circ} \mathrm{C}$ under $\mathrm{N}_{2}$ atmosphere. After ending the reaction, the final product microspheres were collected by filtering. Then they were washed with water and ethanol in turn several times. Finally they were dried under vacuum at $50{ }^{\circ} \mathrm{C}$ to a constant weight, and the immobilized TEMPO complex catalyst (designated as TEMPO/CPGMA) was gained. Furthermore, by varying the feed ratio, the reaction temperature, and the solvent, the effects of these factors on the immobilized reaction were examined.

\subsection{Characterization of catalysts}

The chemical structure of the crosslinked microbeads CPGMA and immobilized TEMPO/CPGMA microspheres were characterized by FT-IR (Perkin-Elmer 1700 infrared spectrometer, Perkin-Elmer Company, USA). Their morphology and size (particle diameter) were characterized by scanning electron microscopy (SEM, 438VP scanning electron microscopy, LEO 
company, UK) and an optical microscope (XSZ-4 optical microscope with micrometer, Taiyuan Optics Instrument Factory, China). The amount of epoxy groups on the CPGMA was calculated from the monomer feed ratio $(6.17 \mathrm{mmol} / \mathrm{g})$. The amount of epoxy groups on the TEMPO/CPGMA surface was determined by the pyridine-hydrochloride method [25], and the immobilized amount (mmol/g) of TEMPO was calculated. The immobilized TEMPO/CPGMA catalysts used in this study have an immobilized amount of $3.14 \mathrm{mmol} / \mathrm{g}$.

\subsection{Catalytic oxidation of benzyl alcohol with molecular oxygen}

Benzyl alcohol (5 mL, AR grade, Guoyao Chemicals Co. Ltd., Beijing, China) and $50 \mathrm{~mL}$ of DMF as solvent were placed into a reactor equipped with a mechanical stirrer, a reflux condenser, a thermometer, and an $\mathrm{O}_{2}$ inlet, followed by adding $0.90 \mathrm{~g}$ of TEMPO/CPGMA microspheres and $0.242 \mathrm{~g}$ of $\mathrm{CuCl}$. Oxygen at normal pressure was passed into the mixture at a fixed flow rate $(15 \mathrm{~mL} / \mathrm{min})$. The oxidation reaction was performed at 25 ${ }^{\circ} \mathrm{C}$ with stirring for $20 \mathrm{~h}$. Samples of the reaction mixture were taken at fixed time intervals, and the analysis was carried out immediately by gas chromatography (GC) with the area-normalization standard method ( $\mathrm{N}_{2}$, HP-5 capillary column, FID detector). The GC analysis indicated that benzaldehyde was the only product, showing that this catalytic oxidation system has excellent selectivity. The benzaldehyde yield and conversion of benzyl alcohol were calculated from the GC data. After finishing the reaction, the TEMPO/CPGMA microspheres were collected by filtration, and washed alternately with DMF and ethanol. In order to remove adsorbed molecules on the catalyst, the microspheres were soaked in ammonia for $12 \mathrm{~h}$ and then washed with distilled water. After drying under vacuum to a constant weight, TEMPO/CPGMA was obtained for recycling.

In order to examine the effects of the main factors on the catalytic oxidation reaction and to optimize the reaction conditions, the molar ratio of main catalyst and co-catalyst, used amount of the solid catalyst, reaction temperature, and solvent were changed in turn, and the catalytic oxidation of benzyl alcohol was carried out under the different conditions.

\section{Results and discussion}

\subsection{Preparation of immobilized TEMPO complex catalyst TEMPO/CPGMA}

In this work, molecular design was used to get free radicals immobilized on the surface of polymer microspheres containing epoxy groups. The crosslinked microspheres, CPGMA, were prepared by suspension copolymerization of GMA and EGDMA, and EGDMA was used as crosslinker. There are abundant epoxy groups on the surface of the CPGMA crosslinked microspheres. 4-OH-TEMPO can be easily bonded on the surface of the crosslinked microspheres by the ring opening reaction of the epoxy groups under alkaline condition. Thus, the immobilized TEMPO/CPGMA microspheres were formed. The process to prepare the immobilized TEMPO/CPGMA microspheres is demonstrated in Scheme 1.

\subsection{Characterization of the crosslinked microspheres and immobilized microspheres}

\subsubsection{FT-IR spectra of the microspheres}

Figure 1 gives the FT-IR spectra of the CPGMA and TEMPO/CPGMA microspheres. In the spectrum of CPGMA, the characteristic absorption band at $1731 \mathrm{~cm}^{-1}$ was attributed to the ester carbonyl groups of GMA and EGDMA. The characteristic absorption of the epoxide rings appeared at 906 and 844 $\mathrm{cm}^{-1}$. The band at $2953 \mathrm{~cm}^{-1}$ is the stretching vibration absorption of the methylene groups of EGDMA and the main chain of the polymer. The band at $3000 \mathrm{~cm}^{-1}$ was ascribed to the stretching vibration absorption of the methyl groups of GMA. The appearances of these bands revealed that the crosslinked

(1) Preparation of crosslinked polymer microspheres CPGMA

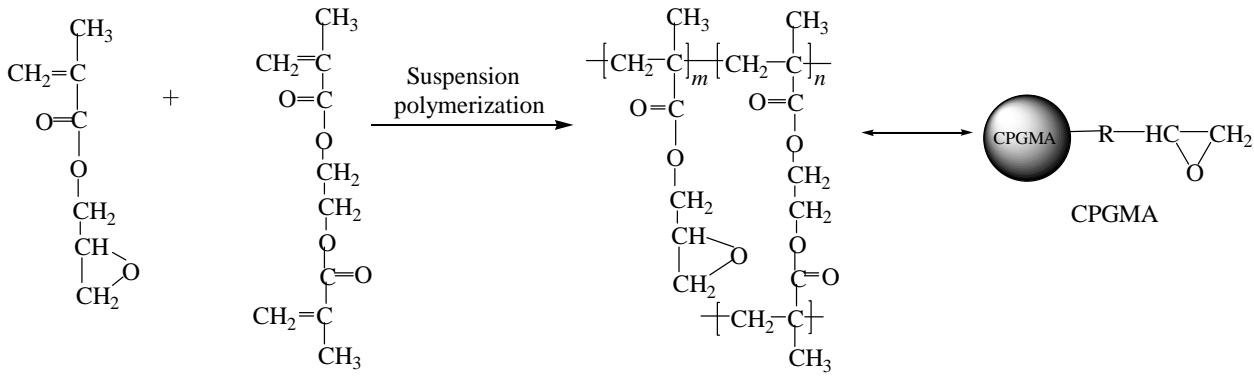

(2) Immobilization of TEMPO on CPGMA microspheres
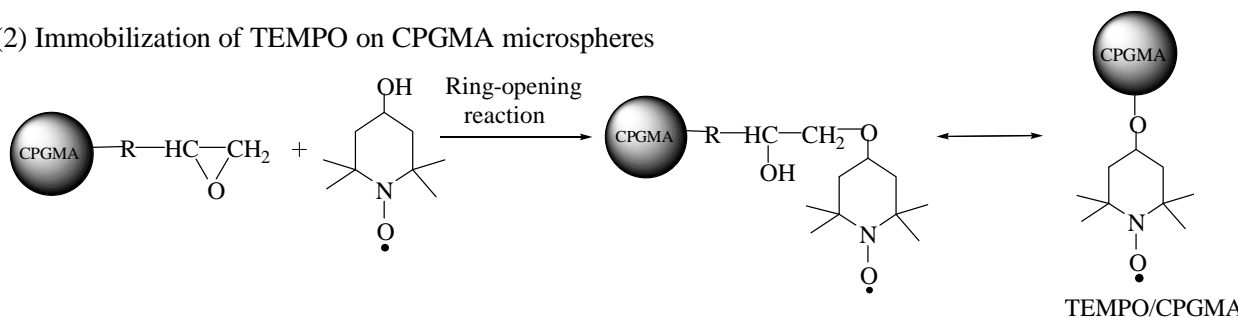

Scheme 1. Chemistry of preparing the TEMPO/CPGMA heterogeneous catalyst. 


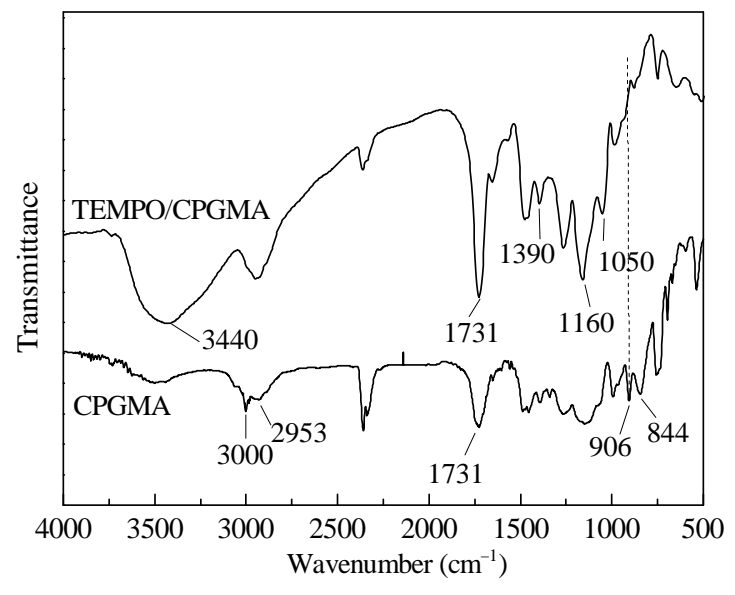

Fig. 1. FT-IR spectra of the two microspheres.

copolymerization of GMA and EGDMA has occurred, and crosslinked CPGMA microspheres were formed.

The FT-IR spectrum of TEMPO/CPGMA has some absorption bands different from those of the CPGMA crosslinked microspheres. In the spectrum of the TEMPO/CPGMA microspheres, the characteristic absorption bands of the epoxy groups at 906 and $844 \mathrm{~cm}^{-1}$ were much weakened, whereas the characteristic absorption band of the free radicals group $\mathrm{N}-\mathrm{O}$ and ether group C-O-C appeared at 1390 and $1160 \mathrm{~cm}^{-1}$, respectively. The strong absorption band at $3440 \mathrm{~cm}^{-1}$ representing the $-\mathrm{OH}$ stretching vibration absorption is due to 4-OH-TEMPO grafted onto the CPGMA crosslinked microspheres, which is a result of the ring opening reaction of epoxy. Therefore, the FT-IR spectrum data fully demonstrated that 4-OH-TEMPO was bonded onto the crosslinked CPGMA microspheres by the ring opening reaction of epoxy, and immobilized TEMPO/CPGMA microspheres were prepared.

\subsubsection{Morphology of the microspheres}

Figure 2 presents the SEM images of the crosslinked CPGMA microspheres and immobilized TEMPO/CPGMA microspheres. The CPGMA microspheres were more spherical and had a more uniform particle size. After the immobilization reaction, the immobilized TEMPO/CPGMA microspheres were still spherical, but the surface of the microspheres had became a little rough and scraggy, which was a result of the macromolecular reaction (ring opening reaction of epoxy groups) on the surface of the microspheres, indicating the immobilization of TEMPO on the microspheres.

\subsection{Effects of main factors on the immobilization of TEMPO}

\subsubsection{Effect of reactant ratio}

In the reaction system described in Section 2.2, with a fixed amount of CPGMA and volume of solvent, the reaction was carried out by changing the molar ratio of 4-OH-TEMPO to the epoxy groups on the microspheres. Figure 3 gives the curves of the immobilized amount (IA) of TEMPO versus time at different reactant ratios. With increasing molar ratio between

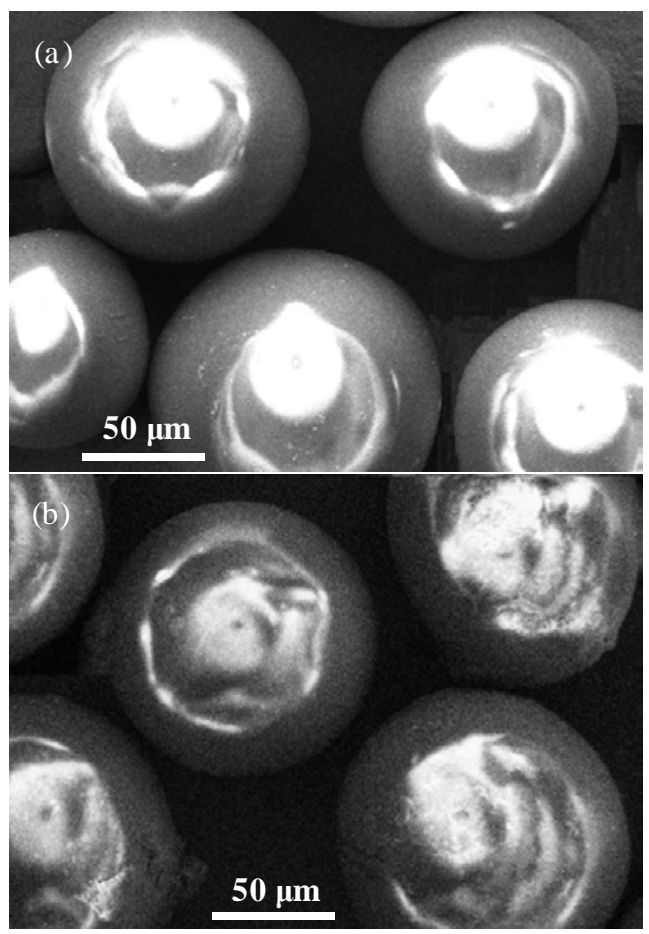

Fig. 2. SEM photographs of the CPGMA and TEMPO/CPGMA microspheres.

4-OH-TEMPO and epoxy groups on the microspheres, the immobilized amount of TEMPO increased rapidly. The ring opening reaction of epoxy groups and 4-OH-TEMPO is a nucleophilic substitution reaction with the $\mathrm{S}_{\mathrm{N}} 2$ reaction mechanism because increasing the concentration of 4-OH-TEMPO, which was used as the nucleophilic reagent, accelerated the reaction rate, resulting in the increase amount of immobilized TEMPO. However, as the concentration increased beyond a certain value, the increase in immobilized amount began to slow down. As can be seen from Fig. 3, the curve of the reactant ratio of 1:2.0 is close to that with $1: 3.0$. For this system, an adequate reactant ratio should be selected as 1:2.0, with which the immobilized amount of TEMPO can reach $3.14 \mathrm{mmol} / \mathrm{g}$.

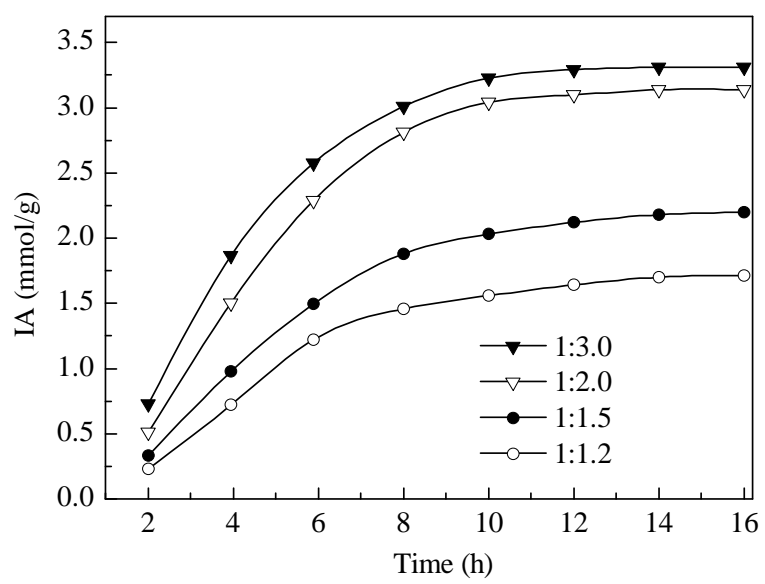

Fig. 3. Immobilized amount (IA) of TEMPO on TEMPO/CPGMA microspheres versus time at different 4-OH-TEMPO: epoxy groups ratios. Reaction conditions: DMF as solvent, $85^{\circ} \mathrm{C}$. 


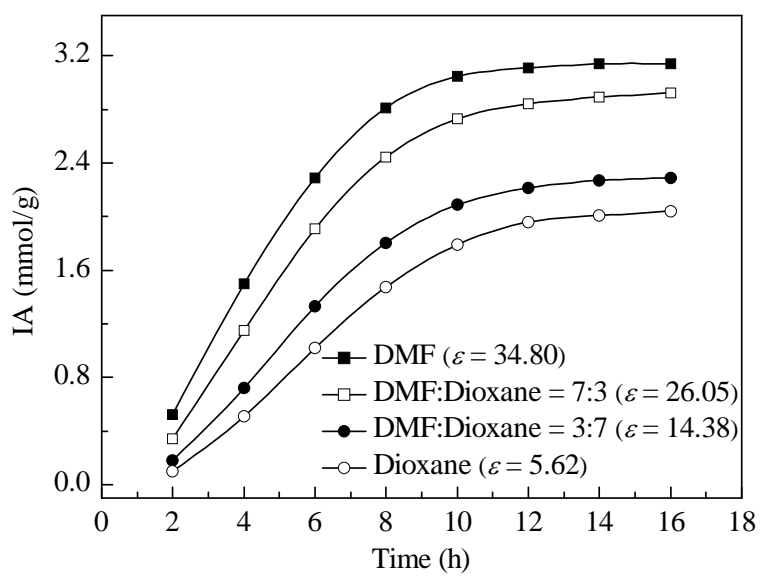

Fig. 4. TEMPO bonded amount obtained using different solvents. Reaction conditions: $85{ }^{\circ} \mathrm{C}$, feed ratio 1:1.2. $\varepsilon$ : Dielectric constants of the solvents at $25^{\circ} \mathrm{C}$, and the dielectric constant of the mixed solvent was calculated according to molar ratio of the two solvents.

\subsubsection{Effect of solvent polarity}

By fixing the other reaction conditions, the ring opening reaction between epoxide groups and 4-OH-TEMPO was conducted using four solvents with different polarities and dielectric constants $(\varepsilon)$ : DMF, 1,4-dioxane, mixture of DMF and 1,4-dioxane $(\mathrm{v} / \mathrm{v}=7: 3)$, and mixture of DMF and 1,4-dioxane $(\mathrm{v} / \mathrm{v}=3: 7)$. Figure 4 presents the immobilized amount of TEMPO versus time using the different solvents.

The polarity of the four solvents was in the order of DMF > $\mathrm{DMF}+1,4$-dioxane $(\mathrm{v} / \mathrm{v}=7: 3)>\mathrm{DMF}+1$,4-dioxane $(\mathrm{v} / \mathrm{v}=3: 7)$ $>1,4$-dioxane. DMF was the best solvent, while 1,4-dioxane was the worst. This order is coincident with the polarity of the four solvents. That is, a higher solvent polarity gave more immobilized amount.

The solvent polarity has a large effect on the immobilization reaction. The possible reason for this is as follows. It was found by experiment that the four solvents have good swelling property on the crosslinked CPGMA microspheres, that is, the crosslinked network can be fully stretched, and the epoxy groups of the macromolecular chains and nucleophilic reagent have good contact with each other. A higher solvent polarity gives a stronger dipole-dipole interaction of solvent and nucleophilic reagent, which is helpful for removing the hydroxyl hydrogen protons and attacking the epoxy groups with 4-OH-TEMPO. Based on this, the nucleophilic substitution reaction is promoted, resulting in the enhancement of the immobilized amount. Therefore, DMF should be selected as a suitable solvent for this reaction.

\subsubsection{Effect of temperature}

By fixing the other reaction conditions, the immobilization reaction of TEMPO was performed with changing of the temperature of the ring opening reaction. Figure 5 gives the immobilized amount of TEMPO versus time at different temperatures. The results clearly showed that at lower temperatures, the immobilized amount was low due to the lower efficiency of the ring opening reaction. The reaction rate increased with temperature, resulting in higher immobilized amount of

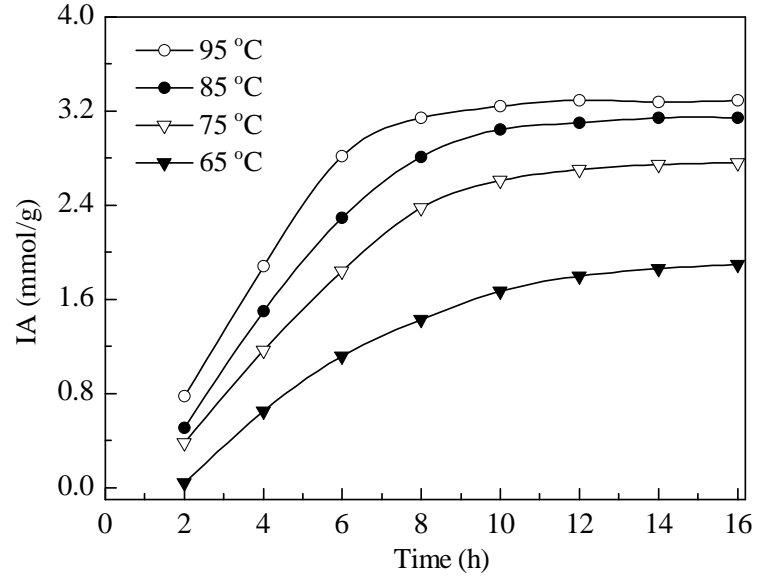

Fig. 5. TEMPO bonded amount obtained at different temperatures. Reaction conditions: DMF as solvent, feed ratio 1:1.2.

TEMPO in the same period of time. Because the immobilized amount of TEMPO at $85{ }^{\circ} \mathrm{C}$ was very close to that at $95{ }^{\circ} \mathrm{C}$, a suitable reaction temperature is $85^{\circ} \mathrm{C}$.

\subsection{Catalytic characteristics of TEMPO/CPGMA in the oxidation of benzyl alcohol with molecular oxygen}

\subsubsection{Catalytic activity and mechanism}

The oxidation of benzyl alcohol was conducted in the following catalyst systems: (1) TEMPO/CPGMA and CuCl (molar ratio 1:1.2); (2) TEMPO/CPGMA; (3) $\mathrm{CuCl}$; (4) without catalyst. In the above (1) and (2) catalyst systems, the immobilized amount of TEMPO on TEMPO/CPGMA was $3.14 \mathrm{mmol} / \mathrm{g}$. Figure 6 gives the benzaldehyde yield versus time in the four systems. It indicates that the oxidation of benzyl alcohol nearly did not occur without catalyst. When some primary catalyst TEMPO/CAGMA or cocatalyst $\mathrm{CuCl}$ were introduced, benzaldehyde was produced with very low yield. For the co-catalyst system composed of TEMPO/CPGMA and $\mathrm{CuCl}$, the yield of benzaldehyde was much enhanced, and it was up to $90 \%$ when the reaction time was $20 \mathrm{~h}$. As compared to an immobilized TEMPO loaded on a molecular sieve and $\mathrm{CuCl}$ system (which

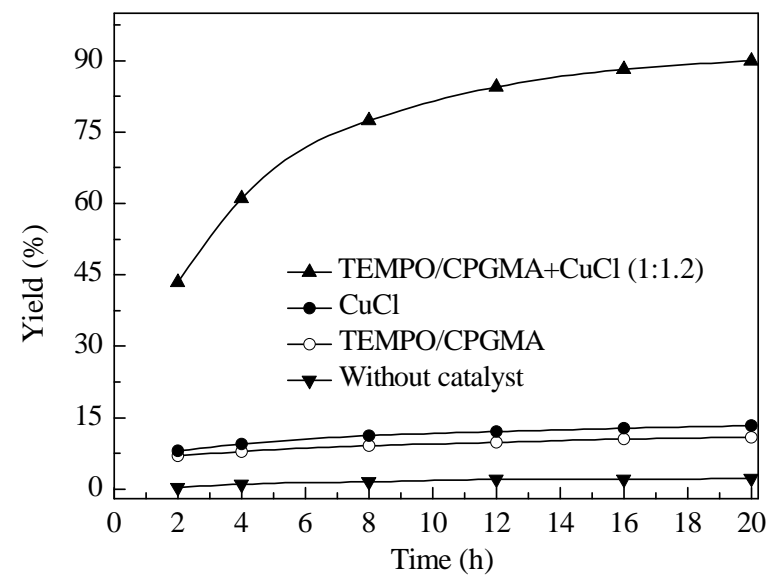

Fig. 6. Benzaldehyde yield with time using different catalyst systems. Reaction conditions: $25^{\circ} \mathrm{C}, \mathrm{DMF}$ as solvent, $\mathrm{O}_{2}$ at atmospheric pressure. 
gave after $48 \mathrm{~h}$, the yield of benzaldehyde of 35\%) reported previously [26], it is obvious that the co-catalyst system consisting of the immobilized TEMPO designed and prepared in this investigation and $\mathrm{CuCl}$ has a higher catalytic activity. This showed that the co-catalyst system consisting of TEMPO/ CPGMA and $\mathrm{CuCl}$ is a highly effective catalyst system for the oxidation of primary alcohols to the corresponding aldehyde.

The oxidation of alcohols can be effectively catalyzed by the TEMPO catalyst, and the catalytic mechanism is the oxoaminium salt cation process $[7,10,27]$, which is not a free radical reaction mechanism. In the oxidation of benzyl alcohol with the above co-catalyst system, the reaction mechanism is suggested as follows (Scheme 2): first, the co-catalyst $\mathrm{CuCl}$ is oxidized to $\mathrm{Cu}$ (II) under oxygen; then the one-electron oxidation of TEMPO takes place, and the oxoaminium salt cation with strong oxidizability is obtained; then the oxoaminium salt cation obtains hydrogen from benzyl alcohol under mild conditions, resulting in the highly effective oxidation of benzyl alcohol into benzaldehyde. At the same time, the catalyst is returned as the reduced TEMPOH, and one catalytic oxidation cycle is completed. Based on this catalytic mechanism without free radicals, the oxidation of benzyl alcohol into the corresponding carboxylic acid is avoided.

\subsubsection{Effect of added amount of CuCl on the catalytic oxidation reaction}

By fixing the other reaction conditions, the oxidation of benzyl alcohol was performed with changing of the dosage of the $\mathrm{CuCl}$ co-catalyst. Benzaldehyde yields versus time are shown in Fig. 7. Figure 7 shows that with an increase of added amount of $\mathrm{CuCl}$, the benzaldehyde yield is increased. When the molar ratio of primary TEMPO catalyst and $\mathrm{CuCl}$ cocatalyst is $1: 1.2$, and the reaction time is $20 \mathrm{~h}$, the benzaldehyde yield was about $90 \%$. If the added amount of $\mathrm{CuCl}$ was further increased (TEMPO: $\mathrm{CuCl}=1: 1.5$ ), the benzaldehyde yield was barely changed, i.e., too much $\mathrm{CuCl}$ no longer affects the oxidation reaction. Therefore, for this catalytic oxidation system, the proper molar ratio of primary catalyst to co-catalyst is 1:1.2.

\subsubsection{Effect of the amount of the catalytic system on the oxidation reaction}

The oxidation of benzyl alcohol was conducted using differ-

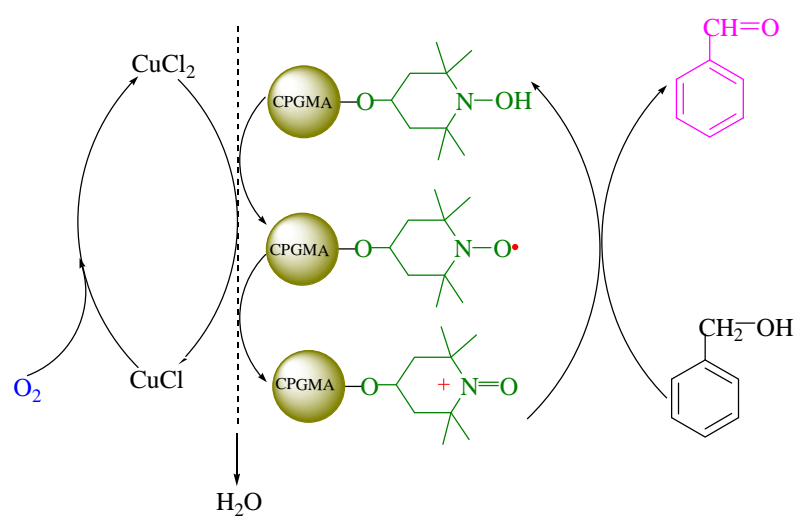

Scheme 2. Catalytic mechanisam of TEMPO/CPGMA+CuCl catalyst in the oxidation of benzyl alcohol to benzaldehyde by $\mathrm{O}_{2}$.

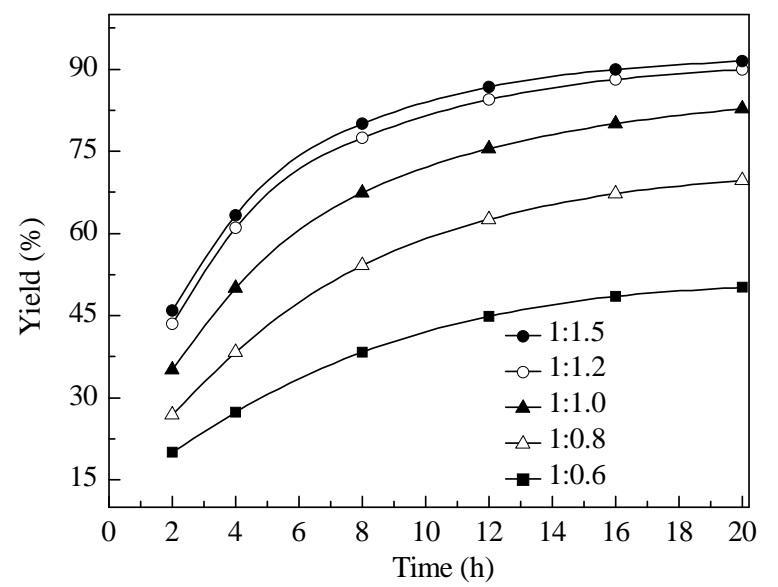

Fig. 7. Benzaldehyde yield with reaction time with different added amounts of CuCl. Reaction conditions: TEMPO/CPGMA is $0.90 \mathrm{~g}$, DMF as solvent, $25^{\circ} \mathrm{C}, \mathrm{O}_{2}$ at atmospheric pressure.

ent amounts of TEMPO/CPGMA when the molar ratio of TEMPO and $\mathrm{CuCl}$ was 1:1.2 and the other reaction conditions were fixed. The yield of benzaldehyde with time is shown in Fig. 8. It can be found that the yield of benzaldehyde increased with increasing amount of TEMPO/CPGMA, which is in accord with the characteristics of the heterogeneous catalytic reaction. However, when the amount of TEMPO/CPGMA was increased to $0.90 \mathrm{~g}$ and the yield of benzaldehyde reached $90 \%$, the increased yield with increasing amount of catalyst was very small. So for this reaction system, the suitable amount of TEMPO/CPGMA is $0.90 \mathrm{~g}$ (the molar ratio of TEMPO and $\mathrm{CuCl}$ is 1:1.2).

\subsubsection{Catalytic activity of reused TEMPO/CPGMA}

To investigate the catalytic activity of reused TEMPO/ CPGMA, the supported catalyst used in each catalytic oxidation was separated from the reaction mixture for reuse. $\mathrm{CuCl}$ and TEMPO/CPGMA were used together as composite catalysts. The experimental results are shown in Fig. 9. During the reuse of 6 times, the catalytic activity declined a little at the second

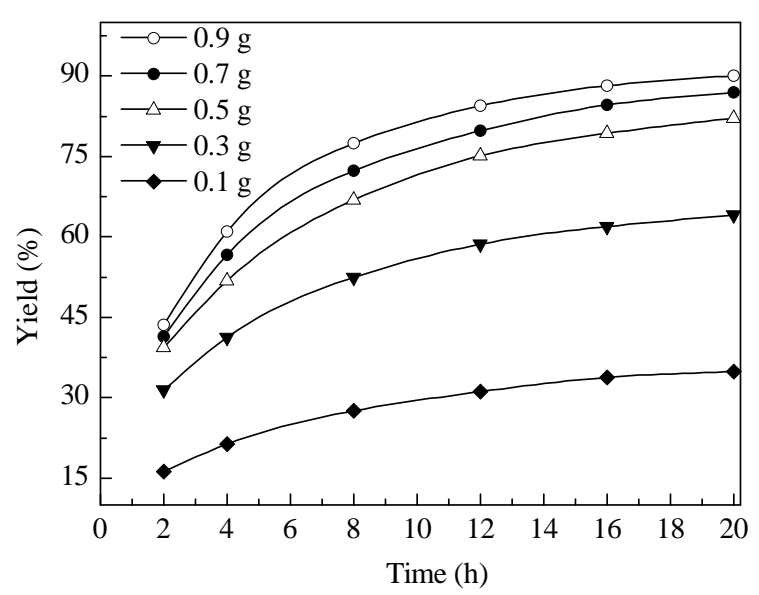

Fig. 8. Benzaldehyde yield with reaction time with different amounts of co-catalyst. Reaction conditions: $25^{\circ} \mathrm{C}, \mathrm{DMF}$ as solvent, main catalyst: sub-catalyst $=1: 1.2, \mathrm{O}_{2}$ at atmospheric pressure. 


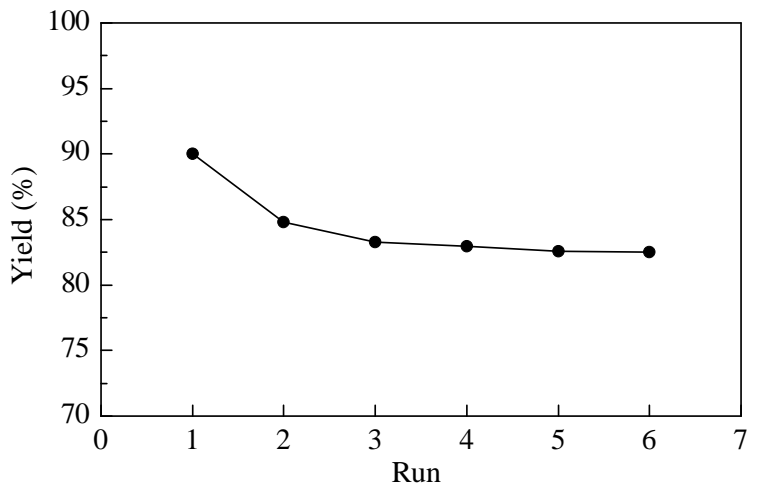

Fig. 9. Effect of cycle number on catalyst activity. Reaction conditions: TEMPO/CPGMA is $0.90 \mathrm{~g}, 25^{\circ} \mathrm{C}, \mathrm{DMF}$ as solvent, main catalyst: sub-catalyst $=1: 1.2, \mathrm{O}_{2}$ at atmospheric pressure.

recycle (benzaldehyde yield fallen to $85 \%$ from 90\%); after that, the catalytic activity was quite stable (benzaldehyde yield $>83 \%$ ). In addition, the spherical shape of TEMPO/CPGMA was kept well during the recycling, and their appearance did not show any significant change. Therefore, it can be concluded that this immobilized catalyst has excellent reuse performance.

\section{Conclusions}

TEMPO-immobilized microspheres, TEMPO/CPGMA, were prepared by the ring opening reaction between the epoxy groups on the CPGMA microspheres and 4-OH-TEMPO, and were successfully applied in the oxidation reaction of benzyl alcohol using molecular oxygen. The ring opening reaction between the epoxy groups and 4-OH-TEMPO is a nucleophilic substitution reaction with the $\mathrm{S}_{\mathrm{N}} 2$ reaction mechanism. DMF is an appropriate solvent and a suitable temperature is $85{ }^{\circ} \mathrm{C}$. With a co-catalyst system consisting of TEMPO/CPGMA and $\mathrm{CuCl}$, benzyl alcohol was transformed into benzaldehyde effectively and mildly. In the oxidation reaction of benzyl alcohol using molecular oxygen as an oxygen source, the co-catalyst system constituted by TEMPO/CPGMA and $\mathrm{CuCl}$ exhibited high catalytic activity, and effectively transformed benzyl alcohol to benzaldehyde as the sole product, displaying excellent selectivity at normal temperature and pressure $(100 \%$ selectivity of benzaldehyde, $90 \%$ yield). The results showed that a suitable molar ratio of the TEMPO/CPGMA main catalyst to the $\mathrm{CuCl}$ co-catalyst is $1: 1.2$. The suitable amount of TEMPO/CPGMA main catalyst is $0.90 \mathrm{~g}$. This immobilized catalyst TEMPO/ CPGMA has excellent recycling and reuse property.

\section{References}

[1] Zhu C J, Ji L, Wei Y Y. Catalysis Commun, 2010, 11: 1017

[2] Fall A, Sene M, Gaye M, Gómez G, Fall Y. Tetrahedron Lett, 2010, 51: 4501

[3] Hu Z Z, Kerton F M. Appl Catal A, 2012, 413-414: 332

[4] Jiang N, Ragauskas A J. Tetrahedron Lett, 2005, 46: 3323

[5] Tan R, Liu C, Feng N D, Xiao J, Zheng W G, Zheng A M, Yin D H. Microporous Mesoporous Mater, 2012, 158: 77

[6] Rahimi R, Gholamrezapor E, Naimijamal M R. Inorg Chem Commun, 2011, 14: 1561

[7] Liaigre D, Breton T, Belgsir E M. Electrochem Commun, 2005, 7: 312

[8] Liu L, Ji L Y, Wei Y Y. Catal Commun, 2008, 9: 1379

[9] Mei Z W, Omote T, Mansour M, Kawafuchi H, Takaguchi Y, Jutand A, Tsuboi S, Inokuchi T. Tetrahedron, 2008, 64: 10761

[10] Benaglia M, Puglisi A, Holczknecht O, Quicib S, Pozzi G. Tetrahedron, 2005, 61: 12058

[11] Yang G Y, Guo Y C, Wu G H, Zheng L W, Song M P. Prog Chem, 2007, 19: 1727

[12] Huang B, Zhang N, Hong S G, Cai H.J Mol Catal (China) (黄斌, 张宇, 洪三国, 蔡琥. 分子催化), 2009, 23: 377

[13] Wang Q F, Zhang Y, Zheng G X, Tian Z Z, Yang G Y. Catal Commun, 2011, 14: 92

[14] Wang X L, Liang X M. Chin J Catal (王心亮, 梁釒金沝, 催化学报), 2008, 29: 935

[15] Herath A C, Becker J Y. Electrochim Acta, 2008, 53: 4324

[16] Cecchetto A, Fontana F, Minisci F, Recupero F. Tetrhedron Lett, 2001, 42: 6651

[17] Liu L, Ma J J, Xia J Y, Li L D, Li C L, Zhang X B,Gong J Y. Catal Commun, 2011, 12: 323

\section{Graphical Abstract}

Chin. J. Catal., 2013, 34: 1776-1786 doi: 10.1016/S1872-2067(12)60651-2

Immobilized 2,2,6,6-tetramethyl-piperidinyl-1-oxy catalyst on polymer microspheres and its catalytic oxidation of benzyl alcohol with molecular oxygen

Yiling Yu, Baojiao Gao*, Yanfei Li

North University of China

2,2,6,6-Tetramethyl-piperidinyl-1-oxy (TEMPO) was successfully immobilized on crosslinked polymer microspheres containing epoxy groups by the ring opening reaction between the epoxy group on the polymer microspheres and 4-OH-TEMPO, giving immobilized TEMPO/CPGMA microspheres. A co-catalyst system of TEMPO/CPGMA and $\mathrm{CuCl}$ efficiently catalyzed the oxidation of benzyl alcohol to benzaldehyde under mild conditions.

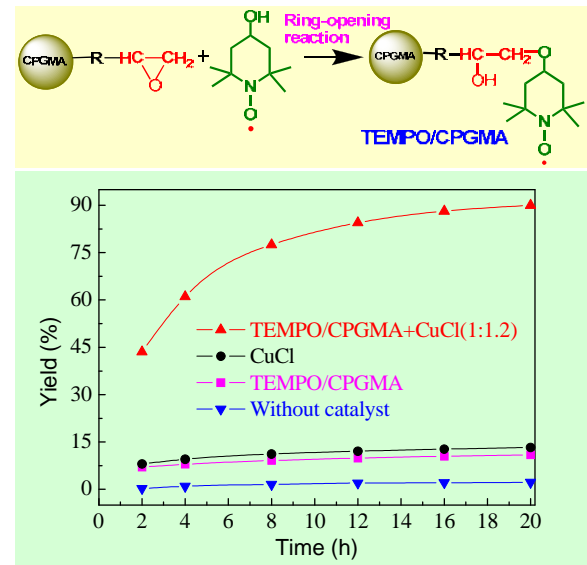


[18] Dijksman A, Arends I W C E, Sheldon R A. Chem Commun, 2000, 271

[19] Testa M L, Ciriminna R, Hajji C, Garcia E Z, Ciclosi M, Arques J S, Pagliaro M. Adv Synth Catal, 2004, 346: 655

[20] Liu L, Ma J J, Ji L Y, Wei Y Y.J Mol Catal A, 2008, 291: 1

[21] Gilhespy M, Lok M, Baucherel X. Catal Today, 2006, 117: 114

[22] Gilhespy M, Lok M, Baucherel X. Chem Commun, 2005: 1085
[23] Tanyeli C, Gümüș A. Tetrahedron Lett, 2003, 44: 1639

[24] Merbouh N, Francois Thaburet J, Ibert M, Marsais F, Bobbitt J M. Carbohydrate Res, 2001, 336: 75

[25] Anirudhan T S, Senan P. Colloids Surf A, 2011, 377: 156

[26] Brunel D, Fajula F, Nagy J B, Deroide B, Verhoef M J, Veum L, Peters J A, Van Bekkum H. Appl Catal A, 2001, 213: 73

[27] Tsubokawa N, Kimoto T, Endo T. J Mol Catal A, 1995, 101: 45

\title{
含环氧基团的聚合物微球固载2,2,6,6-四甲基哌啶氮氧自由基催化剂的制备 及其催化分子氧氧化苯甲醇
}

\author{
余依玲, 高保娇*, 李艳飞 \\ 中北大学化学工程系, 山西太原030051
}

\begin{abstract}
摘要: 以甲基丙烯酸缩水甘油酯(GMA)为单体, 以乙二醇二甲基丙烯酸酯(EGDMA)为交联剂, 采用悬浮聚合法制得交联聚甲 基丙烯酸缩水甘油酯(CPGMA)微球, 然后以4-羟基-2,2,6,6-四甲基哌啶氮氧自由基(4-OH-TEMPO)为试剂, 使CPGMA微球表面 的环氧基团发生开环反应, 从而制得了 TEMPO固载化微球TEMPO/CPGMA, 考察了制备条件对固载化反应的影响, 并采用多种 方法对微球TEMPO/CPGMA进行了表征. 将微球TEMPO/CPGMA与 CuCl组成共催化体系, 用于分子氧氧化苯甲醇, 考察了反应 条件对催化体系性能的影响. 结果表明, 以含环氧基团的聚合物微球CPGMA为载体, 通过开环反应, 可成功地实现TEMPO的固 载化, 开环反应属 $\mathrm{S}_{\mathrm{N}} 2$ 亲核取代反应, 适宜采用溶剂 $N, N^{\prime}$ 二二甲基甲酰胺和反应温度 $85^{\circ} \mathrm{C}$. 非均相催化剂TEMPO/CPGMA与助催 化剂 $\mathrm{CuCl}$ 构成共催化体系, 在室温、常压 $\mathrm{O}_{2}$ 条件下可高效地将苯甲醇氧化为苯甲醛, 产物选择性和产率分别为 $100 \%$ 和 $90 \%$. 主催 化剂TEMPO与助催化剂 $\mathrm{CuCl}$ 适宜的摩尔比为1:1.2; 主催化剂适宜用量为 $0.90 \mathrm{~g}$. 此外, TEMPO/CPGMA固体催化剂具有良好的 循环使用性能.
\end{abstract}

关键词: 聚甲基丙烯酸缩水甘油酯; 氮氧自由基; 固载; 醇氧化; 分子氧

收稿日期: 2013-05-12. 接受日期: 2013-07-02. 出版日期: 2013-09-20.

*通讯联系人. 电话: (0351)3924795; 传真: (0351)3922118; 电子信箱：gaobaojiao@126.com

基金来源：山西省自然科学基金(201002100843).

本文的英文电子版由Elsevier出版社在ScienceDirect上出版(http://www.sciencedirect.com/science/journal/18722067).

\section{1. 前言}

醇氧化为羰基化合物是有机合成中最重要的化学 转化之一, 在实验室研究和精细化工生产中都占有非常 重要的地位. 该过程传统上需使用一些化学计量的强氧 化剂如 $\mathrm{CrO}_{3}, \mathrm{KMnO}_{4}, \mathrm{MnO}_{2}$ 等, 存在着反应条件苛刻、产 生大量废弃污染物、以及氧化剂成本高等不足 ${ }^{[1-4]}$. 而当 今的化工过程, 要求具有绿色环保性和高原子经济性, 显然, 上述传统的转变过程不适应这一要求. 因此, 需要 大力发展高效环保的醇氧化过程, 其中高性能催化剂是 关键. 除杂多酸及金属卟啉 ${ }^{[5,6]}$ 等催化剂外, 氮氧自由基 催化剂也是实现醇氧化的高效催化剂, 其中, 以均相的 2,2,6,6-四甲基哌啶氮氧自由基(TEMPO)催化剂备受关 注. TEMPO可通过单电子氧化过程转化为相应的氮羰 基阳离子, 这是一个氧化性很强的氧化剂, 可将伯醇和 仲醇快速高转化率、高选择性地氧化为对应的醛或 酮 $^{[7-10]}$, 还可以使用那些环境友好型氧化剂 $\left(\right.$ 如 $\mathrm{H}_{2} \mathrm{O}_{2}$ 、分 子氧等), 从而在温和条件下绿色化地实现醇的氧化转 变 ${ }^{[11-17]}$, 而且由于氮氧基团周围强立体位阻, 使TEMPO
催化剂具有高稳定性的特点 ${ }^{[15]}$.

作为均相催化剂, TEMPO虽然表现出良好的催化 活性和选择性, 但反应后难以分离回收, 不能再循环使 用, 严重制约着催化体系的应用. 将TEMPO化学键合在 固体载体上, 实现TEMPO的固载化, 不但可克服上述缺 点, 而且具有更高的活性以及免于使用助催化剂等特 点 ${ }^{[10,18]}$. 因此, TEMPO的固载化成为目前催化氧化领域 中一个重要的研究课题. 固载TEMPO的载体主要有硅 胶、分子篎、聚合物树脂等 ${ }^{[19-21]}$, 其中, 由于聚合物材料 易于通过化学修饰引入活性基团, 便于TEMPO的化学 键合而备受注目. 例如, 分别以含有羧基(或酸酐基团) 及卤烷基团的聚合物为载体(或载体前躯体), 通过与4羟基-TEMPO (4-OH-TEMPO)发生键合反应, 制备了固 载化的TEMPO催化剂 ${ }^{[22-24]}$.

到目前为止, 固载化TEMPO催化剂的报道还很少, 因此，本文采用悬浮聚合法进行甲基丙烯酸缩水甘油酯 (GMA)的交联聚合, 制得表面含有环氧基团的交联聚合 物微球CPGMA; 然后利用环氧基团与4-OH-TEMPO的 开环反应, 将TEMPO键合在微球表面, 制得非均相催化 
剂TEMPO/CPGMA; 并将其用于室温常压下分子氧氧 化苯甲醇, 并研究非均相催化氧化反应的机理.

\section{2. 实验部分}

\section{1. 交联微球CPGMA的制备}

将 $0.50 \mathrm{~g}$ 聚乙烯醇(聚合度1799, 山西三维化工有限 公司)和 $3.50 \mathrm{~g} \mathrm{NaCl}$ 溶于 $50 \mathrm{~mL}$ 蒸馏水中构成水相; 将 10 $\mathrm{mL}$ 的单体GMA (AR, 苏州南航化工有限公司, 使用前 经减压蒸馏提纯)和 $1 \mathrm{~mL}$ 的交联剂乙二醇二甲基丙烯酸 酯(EGDMA, AR, 山东烟台云开化工有限公司, 使用前 进行减压蒸馏)相混溶, 构成油相. 在装有搅拌器、冷凝 管、导气管的四口瓶中加入水相, 并加热至 $45^{\circ} \mathrm{C}$, 通入 氮气30 min, 然后将油相缓慢滴加到水相中, 在恒温下 搅拌30 min, 使其充分分散形成悬浮体系. 将体系温度 升高到 $55^{\circ} \mathrm{C}$, 加入 $0.10 \mathrm{~g}$ 的引发剂偶氮二异丁腈(AR, 上海化学试剂厂), 在氮气保护下恒温反应 $5 \mathrm{~h}$, 反应结 束后将微球滤出, 用乙醇和蒸馏水多次洗涤, 于 $50{ }^{\circ} \mathrm{C}$ 下真空干燥至恒重, 即制得半透明状的白色交联聚合物 (CP) 微球GMA/EGDMA, 由于GMA是主单体, 故简写为 CPGMA微球.

\subsection{TEMPO在交联微球表面的固载化}

称取 1.0 g CPGMA微球置于装有搅拌器、冷凝管和 导气管的四口瓶中, 加入 $20 \mathrm{~mL}$ 的溶剂 $N, N^{\prime}$-二甲基甲酰 胺(DMF, AR, 天津市博迪化工有限公司)使微球充分溶 胀 $12 \mathrm{~h}$. 再称取 $2.14 \mathrm{~g}$ 4-OH-TEMPO (CP, 上海瑞硕化 工), 用 $30 \mathrm{~mL}$ 的DMF溶解后加入到四口瓶中, 再加入 5 $\mathrm{mL}$ 饱和 $\mathrm{Na}_{2} \mathrm{CO}_{3}$ 溶液, 将体系的温度升至 $85^{\circ} \mathrm{C}$, 恒温摚 拌并在氮气保护下反应 $12 \mathrm{~h}$. 反应结束后滤出微球, 用 蒸馏水与无水乙醇反复多次洗涤, 于 $50{ }^{\circ} \mathrm{C}$ 下真空干燥 至恒重, 即得氮氧自由基固载化微球TEMPO/CPGMA. 同时, 考察反应温度、投料比、溶剂等主要因素对 TEMPO固载化反应的影响.

\section{3. 产物的表征}

采用溴化钾压片法测定 CPGMA微球和 TEMPO/ CPGMA微球的FT-IR(1700型傅里叶红外光谱仪, 美国 Perkin-Elmer公司)谱, 对其化学结构进行表征; 用生物 显微镜(带有测微尺的XSZ-4型双目生物显微镜, 太原光 学仪器厂)测定其粒径(约为 $100 \mu \mathrm{m}$ ); 用扫描电镜(SEM, 438VP型扫描电子显微镜, 英国LEO公司)观察其形貌. 交联微球上环氧基团的含量以单体投料比求得约为 6.17 $\mathrm{mmol} / \mathrm{g}$. 采用吡啶 - 盐酸法 ${ }^{[25]}$, 测 定微球 TEMPO/ CPGMA表面环氧基团的剩余量, 从而测得TEMPO的固
载量(IA)为 $3.14 \mathrm{mmol} / \mathrm{g}$.

\section{4. 苯甲醇的分子氧催化氧化}

在装有摚拌器及冷凝回流管装置的四口烧瓶中, 加 入 $50 \mathrm{~mL}$ DMF和 $5 \mathrm{~mL}$ 苯甲醇, 再加入 $0.90 \mathrm{~g}$ 固载化微球 TEMPO/CPGMA及 $0.242 \mathrm{~g}$ 助催化剂 $\mathrm{CuCl}$, 常压下以恒 定的流速通入 $\mathrm{O}_{2}(15 \mathrm{~mL} / \mathrm{min})$, 搅拌下于 $25^{\circ} \mathrm{C}$ 恒温反应 $20 \mathrm{~h}$. 间隔一定时间取样, 用气相色谱仪分析产物 $\left(\mathrm{N}_{2}\right.$ 气 为载气, HP-5毛细管色谱柱, FID检测). 分析结果表明, 产物苯甲醛是唯一的产物. 反应结束后, 抽滤收集固体 催化剂, 先用DMF和乙醇反复洗涤, 洗涤至滤液中无产 物苯甲醛的紫外特征吸收出现; 然后用氨水浸泡 $12 \mathrm{~h}$, 除去载体上吸附的助催化剂, 再用蒸馏水洗涤, 真空干 燥, 以备循环使用.

本文考察了主催化剂与助催化剂配比、催化剂用量、 反应温度及溶剂种类等对苯甲醇催化氧化性能的影响.

\section{3. 结果与讨论}

\section{1. 制备聚合物固载氮氧自由基非均相催化剂 TEMPO/CPGMA的化学过程}

本文通过分子设计的构思, 将氮氧自由基固载于含 有环氧基团的聚合物微球表面: 首先以GMA为单体, EGDMA为交联剂, 采用悬浮聚合法制备了交联聚合物 微球CPGMA, 在此微球表面含有大量环氧基团; 再以 4-OH-TEMPO 为试剂, 在碱性条件下, 使之与微球 CPGMA表面的环氧基团发生开环反应,从而实现 TEMPO的固载, 制得非均相催化剂TEMPO/CPGMA, 其 制备过程如图式1所示.

\section{2. 交联微球和固载氮氧自由基微球的表征}

\subsection{1. 红外光谱}

图 1 为交联微球 CPGMA 和固载化微球 TEMPO/ CPGMA的FT-IR谱. 由图可见, 在交联微球CPGMA上 $1731 \mathrm{~cm}^{-1}$ 处出现对应于GMA单体单元以及交联剂单体 单元中酯羰基的特征吸收峰; 另外 906 和 $844 \mathrm{~cm}^{-1}$ 处的 谱带为环氧键的特征吸收峰; $2953 \mathrm{~cm}^{-1}$ 处为聚合物主 链亚甲基及EGDMA单体单元中亚甲基的伸缩振动吸收 峰, $3000 \mathrm{~cm}^{-1}$ 处的谱带为GMA 单体单元中甲基的伸缩 振动吸收峰. 由此可见, GMA与EGDMA已发生了交联 共聚合反应，得到了交联微球CPGMA.

当CPGMA固载TEMPO后, 环氧键的特征吸收峰 $\left(906\right.$ 和 $844 \mathrm{~cm}^{-1}$ ) 已大为减弱, 并在 1390 和 $1160 \mathrm{~cm}^{-1}$ 处出 现了两个新峰, 分别对应于 $\mathrm{N}-\mathrm{O}$ 键和 $\mathrm{C}-\mathrm{O}-\mathrm{C}$ 键的特征吸 收峰, 而且于 $3440 \mathrm{~cm}^{-1}$ 处出现了强烈的着基(环氧键开 
环反应的结果)伸缩振动吸收. 由此可见, 4-OH-TEMPO 已与交联微球CPGMA上的环氧基团发生了开环反应, 氮氧自由 TEMPO已键合在了交联微球CPGMA上, 形成 了固载化微球TEMPO/CPGMA.

\subsection{2. 微球的形貌}

图 2 为交联微球 CPGMA 与固载化微球 TEMPO/ CPGMA的SEM照片. 可以看出, 交联微球CPGMA球形 度良好, 粒径比较均匀; 固载TEMPO后其球形度依然保 持良好, 只是表面变得有点粗䊁. 这是由于微球表面发 生了大分子反应(环氧基团开环反应), 将TEMPO键合在 了其表面.

\subsection{TEMPO固载化反应条件的优化}

\subsection{1. 反应物投料比}

保持交联微球CPGMA的投加量为 $1.0 \mathrm{~g}$, 同时保持 溶剂的体积不变, 改变4-OH-TEMPO的投加量, 从而改 变微球表面的环氧基团和4-OH-TEMPO的摩尔投料比, 进行固载化反应, 所得固载化微球TEMPO/CPGMA表面 的TEMPO固载量随时间变化的曲线见图3. 可以清楚地 看出, 随着摩尔投料比的增大, 即随着 4-OH-TEMPO用 量的增大(在溶剂体积不变的情况下, 4-OH-TEMPO浓 度增加), TEMPO的固载量提高, 因而, 4-OH-TEMPO与 环氧基团间的开环反应属双分子亲核取代 $\left(\mathrm{S}_{\mathrm{N}} 2\right)$ 反应, 增 加亲核试剂4-OH-TEMPO的浓度, 使得反应速率加快, 故而固载量增大. 综合起来看, 投料比为 $1: 2.0$ 较适宜, 反 应 $16 \mathrm{~h}$, 可制得 TEMPO固载量为 $3.14 \mathrm{mmol} / \mathrm{g}$ 的微球 TEMPO/CPGMA.

\subsection{2. 溶剂极性}

图 4 为使用 DMF、1,4-二氧六环 (Dioxane)、 DMF+Dioxane混合液 $(\mathrm{v}: \mathrm{v}=7: 3) 、 \mathrm{DMF}+$ Dioxane混合液 $(v: v=3: 7)$ 等四种极性不同具有四种不同介电常数 $\varepsilon$ 的溶 剂时, 所制得的TEMPO/CPGMA表面TEMPO的固载量 随反应时间的变化曲线. 由图4可见, 使用四种不同溶剂 时, TEMPO固载量大小顺序为: $\mathrm{DMF}>\mathrm{DMF}+$ Dioxane (7:3) $>$ DMF+Dioxane (3:7) $>$ Dioxane, 这与它们极性大 小的顺序一致, 即溶剂极性越高, TEMPO固载化反应的 效果越好.

实验发现, 四种溶剂对交联微球CPGMA均有良好 的溶胀性能, 即交联网络能充分伸展开来, 大分子链中 的环氧基团均可以与亲核试剂保持良好的可接近性. 在 此前提条件下, 溶剂对 CPGMA 环氧基团与 4-OHTEMPO之间的取代反应的影响主要来自溶剂的极性, 溶剂的极性越强, 溶剂与亲核试剂4-OH-TEMPO之间的
偶极-偶极相互作用越强, 越有利于其分子中羟基氢质 子的脱去, 有利于4-OH-TEMPO对环氧基团的亲核进攻, 促进了亲核取代反应, 即促进了 TEMPO固载化反应的 进行, 故本文选择DMF为反应溶剂.

\subsection{3. 温度}

图 5 给出了不同反应温度时所制微球 TEMPO/ CPGMA表面TEMPO固载量随时间的变化曲线. 由图可 见, 温度较低时, 开环反应的效果较差, TEMPO的固载 量很低; 随着温度的升高, 相同反应时间内 TEMPO的固 载量增加, 表明反应速度加快. 由于 $85{ }^{\circ} \mathrm{C}$ 时 TEMPO的 固载量已十分接近于 $95^{\circ} \mathrm{C}$ 时, 因此在 $85^{\circ} \mathrm{C}$ 下进行固载 化反应较适宜.

3.4. 非均相催化剂TEMPO/CPGMA在分子氧氧化苯 甲醇过程中的催化特性

\subsubsection{TEMPO/CPGMA的催化活性与催化机理}

使用 TEMPO固载量为 $3.14 \mathrm{mmol} / \mathrm{g}$ 的微球 TEMPO/ CPGMA, 采用以下催化剂体系进行苯甲醇的氧化反应: (1) TEMPO/CPGMA+CuCl (摩尔比 1:1.2); (2) TEMPO/ CPGMA; (3) CuCl; (4)不加催化剂. 图6给出了4种反应 体系中苯甲醛产率随反应时间的变化曲线. 可以看出, 不加催化剂的空白体系基本无反应发生; 单一加入主催 化剂TEMPO/CPGMA或助催化剂 $\mathrm{CuCl}$ 的体系, 苯甲醛 产率很低; 当使用TEMPO/CPGMA+CuCl共催化剂体系 时, 反应 $20 \mathrm{~h}$, 苯甲醛产率可达 $90 \%$. 可见, 固载化微球 TEMPO/CPGMA 与 $\mathrm{CuCl}$ 构成的共催化剂体系, 对分子 氧氧化苯甲醇为苯甲醛的反应具有很高的催化活性, 明 显高于分子篎固载化的TEMPO $+\mathrm{CuCl}$ 体系 ${ }^{[26]}$ (48 h, 苯甲 醛产率35\%), 是实现伯醇氧化为醛的高效催化剂体系.

氮氧自由基TEMPO催化氧化醇的机理目前普遍认 同的是氮羰基阳离子历程 ${ }^{[7,10,27]}$, 这是一非自由基反应 机理. 在本催化氧化体系中, 可能的反应机理为如图式2 所示: 在分子氧的氧化作用下, 助催化剂 $\mathrm{CuCl}$ 首先被氧 化为高价的 $\mathrm{Cu}(\mathrm{II})$, 在其作用下, TEMPO发生单电子氧 化过程, 转化为具有极强氧化性的氮羰基阳离子, 该氧 化剂物种在温和的条件下, 从苯甲醇分子中提取氢, 从 而将其高效地氧化为苯甲醛, 与此同时, 催化剂复原为 还原态的TEMPOH, 完成催化氧化循环. 由于此反应机 理中不存在自由基, 故避免了产物过度氧化为羧酸.

\subsection{2. 助催化剂 $\mathrm{CuCl}$ 投料量对反应性能的影响}

当固定 TEMPO/CPGMA的加料量为 $0.90 \mathrm{~g}, \mathrm{CuCl}$ 的 用量(表示为TEMPO与 $\mathrm{CuCl}$ 的摩尔比)不同时, 苯甲醛的 产率随反应时间变化的曲线见图7. 图7显示, 随着助催 
化剂 $\mathrm{CuCl}$ 用量的增加, 苯甲醛产率增高. 当 TEMPO与 $\mathrm{CuCl}$ 的摩尔比为 $1: 1.2$, 反应 $20 \mathrm{~h}$ 时, 苯甲醛产率约为 $90 \%$, 继续增加 $\mathrm{CuCl}$ 的用量, 反应结果变化不大. 因此, 本体系TEMPO与 $\mathrm{CuCl}$ 的摩尔比为 $1: 1.2$ 较适宜.

\subsection{3. 共催化剂体系用量对催化氧化反应的影响}

图8为共催化剂体系的用量(以TEMPO/CPGMA的 质量计)对苯甲醛产率的影响. 由图可见, 苯甲醛产率随 共催化剂用量的增加而增高, 当催化剂用量增高至一定 量(TEMPO/CPGMA的质量为 $0.90 \mathrm{~g}$ ) 时, 苯甲醛产率达 到 $90 \%$; 继续增加催化剂的用量, 苯甲醛产率的变化很 微小.

\subsection{4. 催化剂的循环使用性能}

图9考察了固载化催化剂TEMPO/CPGMA和 $\mathrm{CuCl}$ 形成共催化体系的重复用使用性能. 可以看到, 在6次循 环实验中, 第二次使用时苯甲醛产率从90\%降至 $85 \%$, 在 其余的4次循环使用过程中, 随着循环使用次数的增加, 苯甲醛产率可基本稳定在 $83 \%$ 以上. 同时发现, 在循环
使用过程中TEMPO/CPGMA微球始终保持良好的球形 度, 外观未发现明显的变化. 由此可见TEMPO/CPGMA 具有良好的重复使用性能.

\section{4. 结论}

利用聚甲基丙烯酸缩水甘油酯交联微球表面的环 氧基团与4-OH-TEMPO之间的开环反应, 将 TEMPO固 载于聚合物微球表面, 提出了一条实现TEMPO固载化 的独特途径. CPGMA的环氧基团与4-OH-TEMPO之间 的开环反应属 $\mathrm{S}_{\mathrm{N}} 2$ 亲核取代反应, 在DMF中于 $85^{\circ} \mathrm{C}$ 下进 行固载化反应较为适宜. TEMPO/CPGMA与助催化剂 $\mathrm{CuCl}$ 构成共催化体系, 可在室温、常压的 $\mathrm{O}_{2}$ 下高效地实 现苯甲醇氧化为苯甲醛, 苯甲醛选择性和产率分别为 $100 \%$ 和 $90 \%$. 适宜的反应条件为 TEMPO 与助催化剂 $\mathrm{CuCl}$ 摩尔比1:1.2, TEMPO/CPGMA用量 $0.90 \mathrm{~g}$ 以及相应 质量的CuCl. 此外, TEMPO/CPGMA催化剂具有良好的 循环使用性能. 